\title{
Is an insecure job better for health than having no job at all? A systematic review of studies investigating the health-related risks of both job insecurity and unemployment
}

Tae Jun Kim ${ }^{*}$ and Olaf von dem Knesebeck

\begin{abstract}
Background: Though previous research repeatedly found that being employed is better for health than having no job at all, evidence suggests that employment is not always beneficial for health. With especially job insecurity reflecting a contemporary health risk for the employed, a systematic review was performed to assess if insecure employment can be as detrimental for health as unemployment, and to determine whether these associations vary according to different health measures and among men and women.
\end{abstract}

Methods: The literature search was conducted in the databases Medline, Embase and PsychInfo. In order to allow a more accurate comparison between the two risk factors, studies were included if the data for job insecurity and unemployment was ascertained from the same sample, and contained a quantitative analysis for both exposures towards one (or more) health outcome(s).

Results: Out of 375 articles, in total, 13 studies were included in the systematic review. In 24 analyses contrasting the health-related associations between job insecurity and unemployment, 16 statistically significant associations were found for each exposure. According to the different health outcomes used, job insecurity and unemployment were strongly related to mental health, whereas job insecurity was more strongly associated with somatic symptoms. Unemployment showed stronger relations with worse general health and mortality. In 4 out of 16 gender-stratified analyses, significant associations between job insecurity/unemployment and health were found for men but not for women. Beyond that, associations were significant or insignificant in both gender groups.

Conclusions: Though there were moderate differences across the health outcomes, overall, it was found that job insecurity can pose a comparable threat to health than unemployment. Policy interventions should therefore not only consider health risks posed by unemployment, but should also aim at the reduction of insecure employment.

\section{Background}

The influence of unemployment on health was investigated in numerous studies. It was consistently found that joblessness is linked to poorer self-rated health, mental illness, more physical complaints, an increased risk for coronary heart diseases and higher all-cause mortality [1-5]. Hereafter, unemployment is recognized as a crucial hazard, whereas paid work is generally known to be potentially health promoting, since it offers financial security, daily

\footnotetext{
* Correspondence: t.kim@uke.uni-hamburg.de

Department of Medical Sociology, University Medical Centre Hamburg-Eppendorf, Martinistrasse 52, 20246 Hamburg, Germany
}

time structures and social inclusion as well as the development of personal identities [6].

While the introduction of a flexible labor-market was initially regarded as an answer to joblessness, studies, however, showed that having any job is not always better than having no job [7-9]. Even though flexible employment relations were accompanied by a major decline of physically dangerous occupations, the simultaneous growth of service-based industries was associated with new psychosocial risks [10], indicating that poor psychosocial working conditions might detriment health to a similar degree when compared to unemployment $[11,12]$. Of these, particularly insecure employment constitutes 
a major work-related stressor that is related to poor self-rated health, increased psychiatric morbidity, high cholesterol, hypertension, and increased incident coronary heart disease [13-16]. Therefore, job insecurity does not only yield a risk for public health, but also concerns a growing number of employees, affecting even the insecure employed that do not necessarily experience future job loss. And with the labor markets becoming increasingly insecure, new challenges to the broader population are posed. In contrast to the actual experience of job loss, job insecurity defines a perceptual phenomenon [17], including the everyday experience of a prolonging uncertainty of the future [18]. This definition of job insecurity should be distinguished from other objective ascertainments of insecure employment, for example temporal employment (fixedterm, part-time) or former fragmented working careers. The current study aims to explore if the subjective threat of losing one's job can affect health similarly to unemployment. We systematically reviewed the literature by focusing on studies that simultaneously investigated job insecurity and unemployment for a broader range of health outcomes. In contrasting the subsamples of the insecure employed and unemployed within a respective study we addressed the following questions: How strong and consistent are the associations between perceived job insecurity and unemployment with health? Do the associations vary depending on the diverse health measures that were used in studies? And since recent studies found that the associations between psychosocial work characteristics, unemployment and health are also influenced by gender [19-26], we additionally examined if the relationship between job insecurity, unemployment and health varies among men and women.

\section{Methods}

\section{Search strategy and inclusion criteria}

The literature search was conducted on $2^{\text {nd }}$ of March 2015. In order to provide insights to the traceability and reproducibility of our findings, this review was performed on the basis of the PRISMA guidelines [27]. A checklist containing the PRISMA guidelines for reporting systematic reviews is available as an appendix (see Additional file 1). Since no other review focused on a simultaneous analysis of job insecurity and unemployment, no restrictions on the publication date were considered. For the screening of potentially eligible studies, the computerized databases MEDLINE, EMBASE and PSYCHINFO were explored for peer-reviewed articles that enclosed the following keywords for job insecurity, unemployment and health: ("job insecurity" OR "job instability" OR "insecure employment" OR "insecure job" OR "insecure work" OR "job security" OR "job stability" OR "secure employment"
OR "secure job" " OR "job uncertainty") AND (unemployment OR "job loss" OR joblessness) AND (health OR "quality of life" OR well-being OR wellbeing OR mortality OR morbidity OR disease* OR illness* OR sickness).

To respond to design-related heterogeneity that is usually found in the comparison of observational studies [28], data on job insecurity and unemployment had to be derived from the same study to minimize bias and control for sample specific characteristics. Additionally, identified records had to entail a quantitative analysis of job insecurity and unemployment with one or more health outcomes. Furthermore, the measurement of job insecurity had to be based on self-reports, since an objective measure (e.g. contractual insecurity or fragmented working careers), does not adequately reflect job insecurity as an involuntarily and subjective stressor [29]. Studies were also excluded if they measured nonemployment instead of unemployment, to eliminate those who have not yet entered the working force (students, trainees) or who have left due to retirement.

\section{Data extraction}

Descriptive characteristics of studies entailed information on author, country (region), research design, study year, follow-up duration (if appropriate), sample size, response rate, mean age, gender distribution and considered confounders. Additionally, the measurement of health outcomes, job insecurity and unemployment were assessed. For the comparison, results for both risk factors were contrasted for each study by focusing on the most informative statistical measurement. In order to gain additional insights on differences between men and women, gender stratified results were extracted from the articles, if available. Though the reference to scientific data analyses may have led to a better estimation of the risk of both perceived job insecurity and unemployment, we decided not to perform a meta-analysis for a couple of reasons: First, number of included studies was rather small. Second, studies substantially varied in their study designs (crosssectional vs. longitudinal studies), their sampling procedures and data collection methods. Third, longitudinal studies were also characterized by large differences in their observation period and the measurement of predictors and outcomes varied across all included studies. Finally, substantial variations in the consideration of confounders were evident, and statistical analyses and the reporting of effect sizes differed from study to study.

\section{Results}

\section{Literature search}

The screening, exclusion and inclusion process was performed on basis of the PRISMA Flowchart (Fig. 1). A total of 375 publications were identified through the databases Medline, Embase and PsychInfo. After removing 


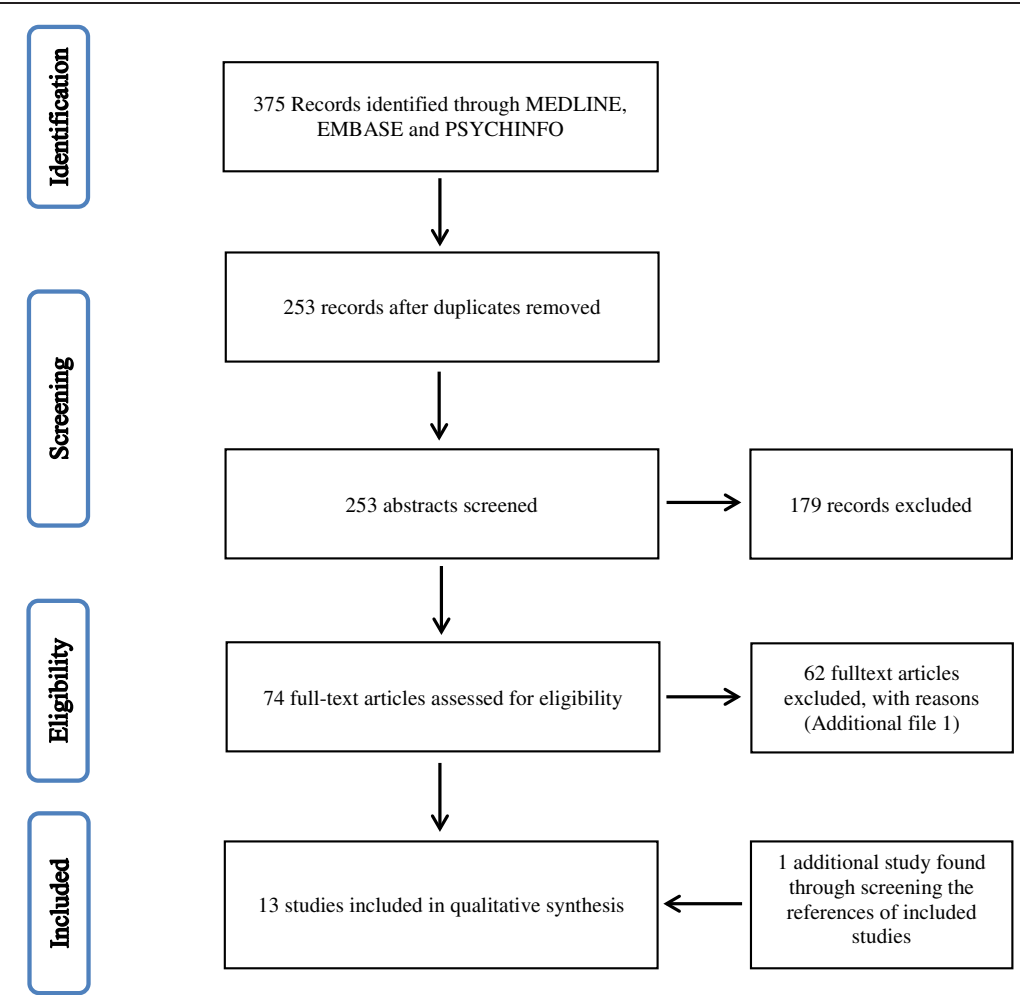

Fig. 1 Selection and inclusion of studies (PRISMA Flow Diagram)

duplications, 253 records remained. After abstract screening, another 179 studies were deselected since they did not address the subject of job insecurity and unemployment in its relation to health. Out of the remaining 74 records that were assessed in full-text and tested for eligibility, 62 articles were excluded for several reasons (see Additional file 2). By screening the grey literature and references of included studies, one additional record was found [30]. Finally, 13 articles were included in the systematic review.

\section{Overview of included studies}

Table 1 summarizes the methodological characteristics of the 13 included studies published between 1997 and 2013. Most of the studies were conducted in Germany and USA. The study samples (total $N=91,085$ ) varied greatly in size. $46 \%$ of the overall data was derived from the USA, $19.8 \%$ from North- and West-Europe, $18.8 \%$ from Russia and $15.3 \%$ from Australia. The mean age of participants included in this review ranged from 29 to 54.8 (excluding four studies in which respective information was not available), whereas only three studies had a mean age lower than 36. In three studies, men were overrepresented. The remaining 9 studies did not reveal major differences towards the distribution of gender, and information was not available for one study.

According to the health outcomes, measures of mental health were most frequently used. Four studies assessed mental health by either recurring to the General Health Questionnaire (GHQ) [31, 32], the Short Form Health Survey (SF-36) [33] or job-related affective well-being, the ladder including dimensions of anxiety, depression, comfort and enthusiasm [34]. Depression was either measured with the subscale of the Hospital Anxiety and Depression scale (HADS) [35], the Center for Epidemiological Studies Depression Scale (CES-D) [30, 36] or with the Patient Health Questionnaire (PHQ) [37, 38]. Anxiety was also ascertained with the subscale of HADS [35] and PHQ [37, 38]. Other mental health related indicators were fatigue, measured with the Gießener Beschwerdebogen (GBB) [35], and somatoform disorders, measured with the PHQ [37] as well as psychological distress, ascertained 
Table 1 Methodological characteristics of included studies

\begin{tabular}{|c|c|c|c|c|c|c|c|}
\hline $\begin{array}{l}\text { Author (year) } \\
\text { Country }\end{array}$ & $\begin{array}{l}\text { Research design } \\
\text { (specific population) }\end{array}$ & $\begin{array}{l}\text { Study year } \\
\text { (follow-up) }\end{array}$ & $\begin{array}{l}\text { Sample } \\
\text { size }\end{array}$ & $\begin{array}{l}\text { Baseline resp. } \\
\text { (follow-up rate) }\end{array}$ & Age mean & Male in \% & Covariates in adjusted multivariable model \\
\hline $\begin{array}{l}\text { Amick, } 2002 \\
\text { USA [40] }\end{array}$ & $\begin{array}{l}\text { Cohort study } \\
\text { (working cohort) }\end{array}$ & 1968 (24 years) & 25,413 & n.a. (30.5 \%) & 45.0 & 44.9 & $\begin{array}{l}\text { Age, race, gender, year, family income, family } \\
\text { size, retirement, unemployment, retirement } \\
\text { by age interaction, race by age interaction, } \\
\text { baseline disability, job strain }\end{array}$ \\
\hline $\begin{array}{l}\text { Berth, } 2003 \\
\text { GER [35] }\end{array}$ & $\begin{array}{l}\text { Cross-sectional } \\
\text { study }\end{array}$ & $2002(--)$ & 420 & $72.0 \%(--)$ & 29.0 & 46.8 & - \\
\hline $\begin{array}{l}\text { Berth, } 2005 \\
\text { GER [39] }\end{array}$ & $\begin{array}{l}\text { Cross-sectional } \\
\text { study }\end{array}$ & $2003(--)$ & 419 & $71.0 \%(--)$ & 30.1 & 46.1 & - \\
\hline \multirow{2}{*}{$\begin{array}{l}\text { Burgard, } 2009 \\
\text { USA [36] }\end{array}$} & \multirow{2}{*}{$\begin{array}{l}\text { Two complementary } \\
\text { cohort studies }\end{array}$} & \multirow{2}{*}{$\begin{array}{l}1986 \text { (3 years) } \\
1995 \text { (10 years) }\end{array}$} & 1,867 & $70.0 \%(87.0 \%)$ & 41.2 & 53.6 & \multirow{2}{*}{$\begin{array}{l}\text { Age, gender, race, marital status, household } \\
\text { income, education, job insecurity, involuntarily } \\
\text { job loss, employed at follow-up, self-employed, } \\
\text { part-time, health shock, high blood pressure, } \\
\text { neuroticism, smoking status, self-rated health } \\
\text { and depressive symptoms at baseline }\end{array}$} \\
\hline & & & 1,712 & $61.0 \%(80.0 \%)$ & 43.4 & 43.7 & \\
\hline $\begin{array}{l}\text { Ferrie, } 1997 \\
\text { GB [31] }\end{array}$ & $\begin{array}{l}\text { Cohort study } \\
\text { (subsample } \\
\text { Whitehall-II) }\end{array}$ & 1985 (9 years) & 666 & $73.0 \%{ }^{\mathrm{a}}(81.2 \%)$ & n.a. & 76.7 & Age, grade and baseline value of the variable \\
\hline $\begin{array}{l}\text { Flint, } 2013 \\
\text { GB [32] }\end{array}$ & Cohort study & 1991 (16 years) & 10,494 & $92.0 \%^{\mathrm{b}}(66.2 \%)$ & n.a. & 48.4 & $\begin{array}{l}\text { Age, age }{ }^{2} \text {, education, physical health problems, } \\
\text { spousal joblessness, spousal GHQ-12, marital } \\
\text { status, unemployed spells in past } 12 \text { months, } \\
\text { residence in social housing, substance abuse, } \\
\text { equivalised household income, permanent } \\
\text { sickness }\end{array}$ \\
\hline $\begin{array}{l}\text { Green, } 2011 \\
\text { AUS [33] }\end{array}$ & Cohort study & 2001 (7 years) & 13,969 & $93.5 \%$ (93.3 \%) & 36.1 & n.a. & $\begin{array}{l}\text { Age, marital status, number of children, } \\
\text { education, income, Employability if } \\
\text { unemployed, re-employment difficulty, } \\
\text { personal characteristics (extroversion, } \\
\text { conscientiousness, emotional stability, } \\
\text { openness to experience), long term health } \\
\text { condition, others present in interview, } \\
\text { regional Australia, remote Australia }\end{array}$ \\
\hline $\begin{array}{l}\text { Levenstein, } \\
2001 \text { USA [15] }\end{array}$ & Cohort study & 1965 (29 years) & 6,928 & $86.2 \%$ (39.4 \%) & n.a. & 43.7 & $\begin{array}{l}\text { Age, gender, ethnicity, educational status, } \\
\text { occupational status, not in labor force, } \\
\text { depression and anomy score, BMI, smoking and } \\
\text { alcohol consumption, leisure time physical } \\
\text { activity, having had a medical checkup within } \\
2 \text { years before the follow-up study. }\end{array}$ \\
\hline $\begin{array}{l}\text { Mandal } 2011 \\
\text { USA [30] }\end{array}$ & Cohort Study & 1992 (14 years) & 5994 & 81.6 (88.6 \%) & 54.8 & 48.8 & $\begin{array}{l}\text { Age, gender, ethnicity, educational level, } \\
\text { suffered business closure, displaced x } \\
\text { expectation, got married/partnered, got } \\
\text { separated/divorced/widowed, change in } \\
\text { housing assets, job tenure years, type of } \\
\text { occupation, S\&P } 500 \text { returns }\end{array}$ \\
\hline $\begin{array}{l}\text { Makikangas, } \\
2011 \text { FIN [34] }\end{array}$ & $\begin{array}{l}\text { Cohort study } \\
\text { (Finnish managers) }\end{array}$ & 1996 (10 years) & 1,035 & $64.0 \%$ (38.8 \%) & 41.9 & 95.0 & - \\
\hline $\begin{array}{l}\text { Mewes, } 2013 \\
\text { GER [37] }\end{array}$ & $\begin{array}{l}\text { Cross-sectional } \\
\text { study }\end{array}$ & $2007(--)$ & 2,510 & $61.9 \%(--)$ & 42.0 & 45.5 & - \\
\hline $\begin{array}{l}\text { Perlman, } 2009 \\
\text { RUS [41] }\end{array}$ & Cohort study & 1994 (9 years) & 17,154 & 88.8 \% (59.6 \%) & n.a. & 52.6 & $\begin{array}{l}\text { Age, education, occupation, alcohol, } \\
\text { smoking, material goods, age at entry, } \\
\text { district in Russia, and cluster by household. }\end{array}$ \\
\hline $\begin{array}{l}\text { Zenger, } 2013 \\
\text { GER [38] }\end{array}$ & $\begin{array}{l}\text { Cross-sectional } \\
\text { study }\end{array}$ & $2010(--)$ & 2,504 & $56.2 \%(--)$ & 51.8 & 46.7 & - \\
\hline
\end{tabular}

${ }^{a}$ Since the response rate for the subsample of PSA-respondents was not available, the overall response-rate for the Whitehall-II sample was used; ${ }^{b}$ Data on the follow-up rate were looked up in the manual of the British Household Panel Survey (Taylor et al. 2010 [42]); ${ }^{C}$ Pooled results for age-groups 45-54 and 55-65 Abbreviations: BMI Body-Mass-Index; GHQ General health Questionnaire; S\&P 500 Standard and poor's 500 stock market index

with the Symptom Checklist-9 (SCL-9) [35]. Moreover, five studies examined associations between perceived job insecurity, unemployment and general health. Three studies ascertained self-rated health on a 5-point scale $[31,35,36,39]$, while a single study assessed the individual's satisfaction with one's own health [39]. Other 
outcomes of general health were long-standing illness and number of health problems [31]. Furthermore, a total of four studies assessed somatic symptoms as a health outcome. One study focused on stomach trouble, joint pain, heartache and an index of complaints measured by the GBB [35]. Another study examined the reported frequency of somatic complaints through the PHQ [38], while two studies either ascertained the number of symptoms [31] or hypertension [15]. Mortality was used as a health outcome in two studies $[40,41]$. It has to be mentioned that of the included 13 studies, 5 studies investigated two or more health indicators. In terms of unemployment, three measures were differentiated: (1) former job loss experience, (2) duration of unemployment and (3) actual unemployment.

\section{Major findings for different health outcomes}

In 24 analyses that compared the health-related risks between the subsamples of the insecure employed and unemployed within each study, 16 statistically significant associations were found for job insecurity and unemployment, respectively (Table 2).

In four studies that examined general health, stronger, but inconsistent relations were found for unemployment. In the 14 analyses that investigated the outcome mental health, overall, strong associations were evident for both risk factors. For mortality, a single study found strong and statistically significant associations with unemployment, but not with job insecurity. Concerning the analysis of somatic symptoms, three out of 5 studies found statistically significant relations with job insecurity, whereas only one study found associations with unemployment. The additional differentiation of the measurement of job loss revealed that the unemployment frequency and duration showed stronger associations than the actual unemployment status.

The health-related risks of job insecurity and unemployment for men and women are summarized in Table 3. With regards to the 6 analyses on general health and longstanding illness no statistically significant associations were found for either job insecurity or unemployment among men and women. In the four analyses that focused on the relationship with mental health, no to small differences between men and women emerged. In one study on mortality, statistically significant associations were only found for unemployment, but not for job insecurity. However, this relationship could only be found for unemployed men. In terms of somatic symptoms, statistically significant relations of hypertension with job insecurity and unemployment were only found for men.

\section{Discussion}

\section{Summary of findings}

The aim of this study was to systematically analyze associations of job insecurity and unemployment with health. This is the first systematic review of studies that simultaneously analyze the health risks of job insecurity and unemployment. Although the results for job insecurity and unemployment showed some inconsistencies, it was revealed that both exposures represent significant (work-related) stressors that are associated with impaired health. In summary, the comparison of the two subsamples of the insecure employed and unemployed within studies suggested that job insecurity might be as harmful to health as unemployment, though differences were found for different health outcomes. In this regard, perceived job insecurity was slightly stronger associated with somatic symptoms, whereas stronger relations with unemployment were found for worse general health and an increased mortality risk. For mental health, strong but partly inconsistent associations were found for both risk factors. It has to be considered that the associations were generally stronger for respondents who were currently unemployed or were exposed to longer durations of joblessness. Likewise, former studies have also found that the impact of job insecurity increases over time. Longitudinal studies concentrating on chronic job insecurity and health $[13,43]$ indicate that job insecurity constitutes a chronic stressor which does not immediately affect health, but its impact intensifies on temporal expansion. Especially with respect to the framework of Lazarus and Folkman [44], persistent job insecurity presents a continuous source of uncertainty, in which the ongoing exposition to stress can ultimately impair health [45].

According to gender-specific health risks through job insecurity and unemployment, 9 of 16 analyses revealed statistically insignificant associations between job insecurity, unemployment and health among both genders. In three further cases, statistically significant associations were found that were similar among men and women. In the remaining analyses, associations were significant among men but not among women. This was especially true for mortality and a somatic symptom (hypertension). Generally speaking, the differences between men and women seem to be inconsistent, with insecurely employed or unemployed men having slightly higher risks for impaired health.

\section{Limitations}

Though this was the first review to systematically examine relations between job insecurity, unemployment and ill health, several limitations on the interpretation of our study results should be considered. First, and even though we systematically searched databases for eligible studies, a risk of potentially missing out relevant articles still remains. We attempted to partly reduce this bias by screening the grey literature and references of included studies for additional 
Table 2 Associations between job insecurity, unemployment and health

\begin{tabular}{|c|c|c|c|c|c|c|c|}
\hline No. & Health dimension & Health indicator & Publication & $\begin{array}{l}\text { Unemployment } \\
\text { measurement }\end{array}$ & Statistics & Job insecurity & Unemployment \\
\hline 1. & \multirow[t]{4}{*}{ General health } & $\begin{array}{l}\text { Self-rated health } \\
\text { (5-point scale) }\end{array}$ & Berth 2003 [35] & Job loss experience & F-value (p) & 1.40 (n.s.) & $6.92(<.05)$ \\
\hline 2. & & $\begin{array}{l}\text { Satisfaction with one's } \\
\text { own health (5-point scale) }\end{array}$ & Berth 2005 [39] & Job loss experience & Mean (p) & $6.24(<.01)$ & $6.69(<.05)$ \\
\hline 3. & & $\begin{array}{l}\text { Self-rated health } \\
\text { (5-point scale) }\end{array}$ & $\begin{array}{l}\text { Burgard 2009 } \\
\text { (Cohort 1) [36] }\end{array}$ & Job loss experience & $\begin{array}{l}\text { Unstandardized } \\
\text { OLS coefficient (p) }\end{array}$ & -0.032 (n.s.) & 0.032 (n.s.) \\
\hline 4. & & $\begin{array}{l}\text { Self-rated health } \\
\text { (5-point scale) }\end{array}$ & $\begin{array}{l}\text { Burgard 2009 } \\
\text { (Cohort 2) [36] }\end{array}$ & Job loss experience & $\begin{array}{l}\text { Unstandardized } \\
\text { OLS coefficient ( } p)\end{array}$ & -0.039 (n.s.) & -0.005 (n.s.) \\
\hline 5. & \multirow[t]{7}{*}{ Mental health } & Mental Health (GHQ) & Flint 2013 [32] & Current employment status & $\begin{array}{l}\text { Unstandardized } \\
\text { OLS coefficient ( } p)\end{array}$ & $1.11(<.05)$ & $2.21(<.05)$ \\
\hline 6. & & $\begin{array}{l}\text { Job-related affective } \\
\text { well-being }\end{array}$ & $\begin{array}{l}\text { Makikangas } \\
2011[34]\end{array}$ & Job loss experience & Odds Ratio (p) & $6.32(<.05)$ & $4.86(<.05)$ \\
\hline 7. & & Anxiety (HADS) & Berth 2003 [35] & Job loss experience & F-value (p) & $10.21(<.001)$ & $6.74(<.01)$ \\
\hline 8. & & Anxiety (PHQ-7) & Mewes 2013 [37] & Current employment status & Mean (p) & $2.6(<.001)$ & $2.6(<.001)$ \\
\hline 9. & & \multirow[t]{3}{*}{ Anxiety (PHQ-4) } & \multirow[t]{3}{*}{ Zenger 2013 [38] } & \multirow{3}{*}{$\begin{array}{l}\text { Current employment } \\
\text { status, job loss experience, } \\
\text { unemployment duration }\end{array}$} & \multirow[t]{3}{*}{ F-value (p) } & \multirow[t]{3}{*}{$15.45(<.001)$} & $\begin{array}{l}\text { Frequency: } 24.29 \\
(<.001)\end{array}$ \\
\hline & & & & & & & $\begin{array}{l}\text { Duration: } \\
23.90(<.001)\end{array}$ \\
\hline & & & & & & & $\begin{array}{l}\text { Status: } 4.90 \\
(<.001)\end{array}$ \\
\hline 10. & & Depression (HADS) & Berth 2003 [35] & Job loss experience & F-value $(p)$ & $17.91(<.001)$ & $10.68(<.001)$ \\
\hline 11. & & $\begin{array}{l}\text { Depressive symptoms } \\
\text { (CES-D) }\end{array}$ & $\begin{array}{l}\text { Burgard 2009 } \\
\text { (Cohort 1) [36] }\end{array}$ & Job loss experience & $\begin{array}{l}\text { Unstandardized OLS } \\
\text { coefficient }(p)\end{array}$ & $-0-094$ (n.s.) & 0.042 (n.s.) \\
\hline 12. & & $\begin{array}{l}\text { Depressive symptoms } \\
\text { (CES-D) }\end{array}$ & $\begin{array}{l}\text { Burgard 2009 } \\
\text { (Cohort 2) [36] }\end{array}$ & Job loss experience & $\begin{array}{l}\text { Unstandardized OLS } \\
\text { coefficient }(p)\end{array}$ & 0.053 (n.s.) & 0.020 (n.s.) \\
\hline 13. & & $\begin{array}{l}\text { Depressive symptoms } \\
\text { (CES-D) }\end{array}$ & Mandal 2011 [30] & Job loss experience & $\begin{array}{l}\text { Unstandardized OLS } \\
\text { coefficient }(p)\end{array}$ & $-0-036$ (n.s.) & $0.329(<.05)$ \\
\hline 14. & & $\begin{array}{l}\text { Depressive disorder } \\
\text { (PHQ-9) }\end{array}$ & Mewes 2013 [37] & Current employment status & Mean $(p)$ & $2.9(<.001)$ & $3.6(<.001)$ \\
\hline \multirow[t]{4}{*}{15.} & & \multirow[t]{4}{*}{ Depression (PHQ-4) } & \multirow[t]{4}{*}{ Zenger 2013 [38] } & \multirow[t]{2}{*}{ Current employment status } & \multirow[t]{4}{*}{ F-value (p) } & \multirow[t]{4}{*}{$14.24(<.001)$} & $\begin{array}{l}\text { Frequency: } \\
35.11(<.001)\end{array}$ \\
\hline & & & & & & & $\begin{array}{l}\text { Duration: } 41.74 \\
(<.001)\end{array}$ \\
\hline & & & & Job loss experience & & & \multirow{2}{*}{$\begin{array}{l}\text { Status: } 7.04 \\
(<.001)\end{array}$} \\
\hline & & & & Unemployment duration & & & \\
\hline 16. & & $\begin{array}{l}\text { Somatoform disorder } \\
\text { (PHQ-15) }\end{array}$ & Mewes 2013 [37] & Current employment status & Mean (p) & $3.7(<.001)$ & $3.9(<.001)$ \\
\hline 17. & & $\begin{array}{l}\text { Psychological distress } \\
\text { (SCL-9) }\end{array}$ & Berth 2003 [35] & Job loss experience & F-value $(p)$ & $3.49(<.05)$ & $3.29(<.01)$ \\
\hline 18. & & Fatigue (GBB) & Berth 2003 [35] & Job loss experience & F-value $(p)$ & $5.70(<.01)$ & 2.64 (n.s.) \\
\hline 19. & Mortality & Mortality & Amick 2002 [40] & Current employment status & Odds Ratio (p) & 0.95 (n.s.) & $2.26(<.05)$ \\
\hline 20. & \multirow[t]{5}{*}{$\begin{array}{l}\text { Somatic } \\
\text { symptoms }\end{array}$} & $\begin{array}{l}\text { Stomach trouble } \\
\text { (GBB) }\end{array}$ & Berth 2003 [35] & Job loss experience & F-value $(p)$ & $2.98(<.05)$ & 2.03 (n.s.) \\
\hline 21. & & Joint pain (GBB) & Berth 2003 [35] & Job loss experience & F-value (p) & $2.81(<.05)$ & 2.13 (n.s.) \\
\hline 22. & & Heartache (GBB) & Berth 2003 [35] & Job loss experience & F-value $(p)$ & 2.21 (n.s.) & 1.84 (n.s.) \\
\hline 23. & & $\begin{array}{l}\text { Index of complaints } \\
\text { (GBB) }\end{array}$ & Berth 2003 [35] & Job loss experience & F-value (p) & $5.14(<.01)$ & $3.46(<.05)$ \\
\hline 24. & & Complaints (PHQ-4) & Zenger 2013 [38] & & $F$-value $(p)$ & $5.93(<.01)$ & \\
\hline
\end{tabular}


Table 2 Associations between job insecurity, unemployment and health (Continued)

\begin{tabular}{lll}
\hline & Current employment & Frequency: 6.02 \\
$(<.01)$ & Duration: 10.99 \\
status, job loss experience, & $(<.001)$ & Status: 4.18 \\
unemployment duration & & (<.001) \\
\hline
\end{tabular}

Abbreviations: CES-D Center for Epidemiological Studies Depression Scale; GBB Gießener Beschwerdebogen; GHQ General health Questionnaire; HADS Hospital Anxiety and Depression Scale; $n$.s. not significant; OLS Ordinary least squares; $p$ p-value, PHQ Patient Health Questionnaire; SCL-9 Symptom Checklist-9

(possibly) relevant articles. However, only one additional record was found as only a few studies included both job insecurity and unemployment in their analyses. Second, an extensive summary of a variety of studies certainly yields a risk of bias, since observational studies tend to substantially differ along their study-designs and methodological characteristics. Rather than assessing the unique quality of studies, we decided to focus on the comparison between job insecurity and unemployment within each study to minimize bias and control for these sample-specific characteristics. And although the calculation of an overall effect size may have led to a more precise illustration, a meta-analysis was not considered since the rather small number of included studies varied substantially in their study designs, statistical procedures and use of outcomes. Third, the generalizability of results on the relationship between job insecurity, unemployment and health is limited by the fact that only studies were included that considered both job-related indicators within their analyses. Fourth, health selection effects in the analysis of unemployment remain a major source of bias, since it includes the possibility that persons became unemployed due to their experience of poor health, rather than becoming ill through joblessness. Particularly in cross-sectional studies this scenario is likely to occur. As a consequence, especially the comparison of the health outcome somatic symptoms must be interpreted with caution, since all studies were cross-sectional in design. It has to be mentioned, though, that these risks do not only concern cross-sectional studies as the ascertainments of perceived job insecurity and unemployment in longitudinal studies do not fully cover potential changes during the observation period. As such, no distinction can be made if persons who were unemployed at the baseline survey have found a new job in the meantime or transitioned between unemployment and reemployment over the timeframe. This potential bias is also applicable to the measurement of perceived job insecurity. Fifth, publication bias figures to remain a major issue in systematic reviews that may lead to an overestimation of the associations between job insecurity, unemployment and health; thus further limiting our results. Finally, the fairly small number of studies for some health outcomes threatens the robustness of our findings.

\section{Conclusions}

Despite these limitations, we found that perceived job insecurity and unemployment reflect independent stressors that may constitute major threats for public

Table 3 Gender stratified associations between job insecurity, unemployment and health

\begin{tabular}{|c|c|c|c|c|c|c|c|c|}
\hline \multirow[t]{2}{*}{ No. } & \multirow[t]{2}{*}{ Health dimension } & \multirow[t]{2}{*}{ Health outcome } & \multirow[t]{2}{*}{ Publication } & \multirow[t]{2}{*}{ Statistics } & \multicolumn{2}{|c|}{ Job insecurity } & \multicolumn{2}{|c|}{ Unemployment } \\
\hline & & & & & $\overline{M e n}$ & Women & $\overline{M e n}$ & Women \\
\hline \multirow{2}{*}{$\begin{array}{l}1 . \\
2 .\end{array}$} & \multirow{3}{*}{$\begin{array}{l}\text { General health/ } \\
\text { illness }\end{array}$} & Long-standing illness & Ferrie 1997 [31] & Odds Ratio (p) & 1.06 (n.s.) & 3.39 (n.s.) & 1.62 (n.s.) & 3.76 (n.s.) \\
\hline & & $\begin{array}{l}\text { Number of health problems } \\
\text { (over the last year) }\end{array}$ & Ferrie 1997 [31] & Mean $(p)$ & 1.34 (n.s.) & 2.39 (n.s.) & 1.57 (n.s.) & 2.03 (n.s.) \\
\hline 3. & & $\begin{array}{l}\text { Self-rated health } \\
\text { (5-point scale) }\end{array}$ & Ferrie 1997 [31] & Odds Ratio (p) & 1.52 (n.s.) & 1.40 (n.s.) & 1.54 (n.s.) & 2.08 (n.s.) \\
\hline 4. & \multirow[t]{2}{*}{ Mental health } & Mental Health (GHQ) & Ferrie 1997 [31] & Mean $(p)$ & $\begin{array}{l}2.63 \\
(<.001)\end{array}$ & $2.82(<.05)$ & $2.29(<.01)$ & 2.57 (n.s.) \\
\hline 5. & & Mental Health (SF-36) & Green 2011 [33] & $\begin{array}{l}\text { Unstandardized OLS } \\
\text { coefficient }(p)\end{array}$ & $\begin{array}{l}-5.113 \\
(<.001)\end{array}$ & $\begin{array}{l}-3.137 \\
(<.001)\end{array}$ & $\begin{array}{l}-8.037 \\
(<.001)\end{array}$ & $\begin{array}{l}-8.422 \\
(<.001)\end{array}$ \\
\hline 6. & Mortality & Mortality & Perlman 2009 [41] & Hazards ratio (p) & 0.99 (n.s.) & 1.15 (n.s.) & $1.39(<.05)$ & 0.67 (n.s.) \\
\hline 7. & Somatic symptoms & $\begin{array}{l}\text { Number of symptoms } \\
\text { (in the past fortnight) }\end{array}$ & Ferrie 1997 [31] & Mean (p) & 3.63 (n.s.) & 4.47 (n.s.) & 3.94 (n.s.) & 3.60 (n.s.) \\
\hline 8. & & Hypertension & Levenstein 2001 [15] & Odds Ratio (p) & $1.6(<.05)$ & 1.0 (n.s.) & $2.7(<.05)$ & 0.8 (n.s.) \\
\hline
\end{tabular}

Abbreviations: GHQ General health Questionnaire; n.s. not significant; OLS Ordinary least squares; $p$ p-value; SF-36 Short Form (36) health survey 
health. These associations varied along the use of different health outcomes. Both job insecurity and unemployment were strongly related to mental health. And while job insecurity was stronger associated with somatic symptoms, unemployment showed increased risks for worse general health and mortality. Our results imply that the anticipation of a (potential) job loss is similarly associated with worse health than the actual experience of unemployment. Given that an increasing number of employees are likely to experience their jobs as insecure in the future [46], different public health interventions are necessary to encounter the cumulative health consequences of job loss and insecure employment appropriately. For this, initial insecure employment or unemployment do not only affect subsequent health, as less healthy workers are also likely to end up in less secure jobs and thus promoting the risk for subsequent unemployment. Though labor market policies focusing on increasing flexible employment relations may result in short-term economic benefits, results suggest that insecure employment and job loss may entail increasing long-term consequences for individual and public health, economic productivity and the costs of the health care system. Thus, policies should not only focus on the health risks posed by unemployment, but should also aim at the reduction of job insecurity of the employed.

\section{Additional files}

Additional file 1: PRISMA 2009 Checklist. (DOC 63 kb)

Additional file 2: Reasons for exclusion after fulltext screening.

(DOCX $29 \mathrm{~kb}$ )

\section{Competing interests}

The authors declare that they have no conflict of interest.

\section{Authors' contributions}

TJK and OK developed the research question and carried out the literature search. The inclusion and exclusion of records was discussed by the two reviewers until a consensus was found. TJK extracted the relevant data, wrote the first draft of the manuscript and OK critically revised it. Both authors finalized the manuscript.

\section{Authors' information}

Not applicable.

\section{Acknowledgements}

We thank the reviewers for their helpful comments on a previous draft of the manuscript.

Received: 12 May 2015 Accepted: 22 September 2015

Published online: 29 September 2015

\section{References}

1. Giatti L, Barreto SM, César CC. Unemployment and self-rated health: Neighborhood influence. Soc Sci Med. 2010;71:815-23.

2. Paul Kl, Moser K. Unemployment impairs mental health: Meta-analyses. $J$ Vocat Behav. 2009;74(3):264-82.

3. Grzywacz JG, Dooley D. "Good jobs" to "bad jobs": replicated evidence of an employment continuum from two large surveys. Soc Sci Med. 2003;56(8):1749-60
4. Lundin A, Falkstedt D, Lundberg I, Hemmingsson T. Unemployment and coronary heart disease among middle-aged men in Sweden: 39243 men followed for 8 years. Occup Environ Med. 2014;71(3):183-8.

5. Martikainen P, Mäki N, Jäntti M. The Effects of Unemployment on Mortality following Workplace Downsizing and Workplace Closure: A Register-based Follow-up Study of Finnish Men and Women during Economic Boom and Recession. Am J Epidemiol. 2007;165(9):1070-5.

6. Carlier BE, Schuring M, Lötters FJB, Bakker B, Borgers N, Burdorf A. The influence of re-employment on quality of life and self-rated health, a longitudinal study among unemployed persons in the Netherlands. BMC Public Health. 2013;13:503.

7. Broom DH, D'Souza RM, Strazdins L, Butterworth P, Parslow R, Rodgers B. The lesser evil: Bad jobs or unemployment? A survey of mid-aged Australians. Soc Sci Med. 2006;63(3):575-86.

8. Butterworth P, Leach LS, McManus S, Stansfeld SA. Common mental disorders, unemployment and psychosocial job quality: is a poor job better than no job at all? Psychol Med. 2013;43(8):1763-72.

9. Leach LS, Butterworth P, Strazdins L, Rodgers B, Broom DH, Olesen SC. The limitations of employment as a tool for social inclusion. BMC Public Health. 2010;10:621.

10. Woo J, Postolache TT. The impact of work environment on mood disorders and suicide: Evidence and implications. Int J Disabil Hum Dev. 2008;7(2):185-200.

11. Bültmann U, Kant IJ, Van den Brandt PA, Kasl SV. Psychosocial work characteristics as risk factors for the onset of fatigue and psychological distress: prospective results from the Maastricht Cohort Study. Psychol Med. 2002;32:333-45.

12. Cole DC, Ibrahim S, Shannon HS. Predictors of work-related repetitive strain injuries in a population cohort. Am J Public Health. 2005;95(7):1233-7.

13. Ferrie J, Shipley M, Stansfeld S, Marmot M. Effects of chronic job insecurity and change in job security on self reported health, minor psychiatric morbidity, physiological measures, and health related behaviours in British civil servants: the Whitehall II study. J Epidemiol Community Health. 2002;56(6):450-4.

14. Ferrie JE, Shipley MJ, Newman K, Stansfeld SA, Marmot M. Self-reported job insecurity and health in the Whitehall II study: potential explanations of the relationship. Soc Sci Med. 2005;60(7):1593-602.

15. Levenstein S, Smith MW, Kaplan GA. Psychosocial predictors of hypertension in men and women. Arch Intern Med. 2001;161(10):1341-6.

16. Virtanen M, Nyberg ST, Batty GD, Jokela M, Heikkilä K, Fransson El, et al. Perceived job insecurity as a risk factor for incident coronary heart disease: systematic review and meta-analysis. BMJ. 2013;347:44746.

17. Greenhalg L, Rosenblatt Z. Job insecurity: Toward Conceptual Clarity. Acad Manage Rev. 1984;9(3):438-48.

18. Sverke M, Hellgren J, Näswall K. No security: a meta-analysis and review of job insecurity and its consequences. J Occup Health Psychol. 2002; $7(3): 242-64$.

19. Akhavan S, Bildt CO, Franzén EC, Wamala S. Health in relation to unemployment and sick leave among immigrants in Sweden from a gender perspective. J Immigr Health. 2004;6(3):103-18.

20. Artazcoz L, Benach J, Borrell C, Cortès I. Unemployment and mental health: understanding the interactions among gender, family roles, and social class. Am J Public Health. 2004;94(1):82-8.

21. Artazcoz L, Borrell C, Cortès I, Escribà-Agüir V, Cascant L. Occupational epidemiology and work related inequalities in health: a gender perspective for two complementary approaches to work and health research. J Epidemiol Community Health. 2007;61:39-45.

22. Campos-Serna J, Ronda-Pérez E, Moen BE, Artazcoz L, Benavides FG. Welfare state regimes and gender inequalities in the exposure to work-related psychosocial hazards. Int J Occup Environ Health. 2013;19(3):179-95.

23. Hooftman WE, van der Beek AJ, Bongers PM, van Mechelen W. Is there a gender difference in the effect of work-related physical and psychosocial risk factors on musculoskeletal symptoms and related sickness absence? Scand J Work Environ Health. 2009:35(2):85-95.

24. Hooftman WE, van Poppel MNM, van der Beek AJ, Bongers PM, van Mechelen W. Gender differences in the relations between work-related physical and psychosocial risk factors and musculoskeletal complaints. Scand J Work Environ Health. 2004;30(4):261-78.

25. Reine I, Novo M, Hammarström A. Unemployment and ill health-a gender analysis: results from a 14-year follow-up of the Northern Swedish Cohort. Public Health. 2013;127(3):214-22. 
26. Widanarko B, Legg S, Stevenson M, Devereux J, Eng A, 't Mannetje A, et al. Gender differences in work-related risk factors associated with low back symptoms. Ergonomics. 2012;55(3):327-42.

27. Moher D, Liberati A, Tetzlaff J, Altman DG. Preferred Reporting Items for Systematic Reviews and Meta-Analyses: The PRISMA Statement. Ann Intern Med. 2009;151(4):264-9.

28. Manrique-Garcia E, Sidorchuk A, Hallqvist J, Moradi T. Socioeconomic position and incidence of acute myocardial infarction: a meta-analysis. J Epidemiol Community Health. 2011;65(4):301-9.

29. De Witte H, Näswall K. 'Objective' vs. 'Subjective' Job Insecurity: Consequences of Temporary Work for Job Satisfaction and Organizational Commitment in Four European Countries. Eco Ind Democracy. 2003;24(2):149-88.

30. Mandal B, Ayyagari P, Gallo WT. Job loss and depression: The role of subjective expectations. Soc Sci Med. 2011;72(4):576-83.

31. Ferrie J. Labour Market Status, Insecurity and Health. J Health Psychol. 1997;2(3):373-97.

32. Flint E, Bartley M, Shelton N, Sacker A. Do labour market status transitions predict changes in psychological well-being? J Epidemiol Community Health. 2013;67:796-802.

33. Green F. Unpacking the misery multiplier: how employability modifies the impacts of unemployment and job insecurity on life satisfaction and mental health. J Health Econ. 2010;30(2):265-76.

34. Mäkikangas A, Hyvönen K, Leskinen E, Kinnunen U, Feldt T. A personcentred approach to investigate the development trajectories of job-related affective well-being: A 10-year follow-up study. J Occup Organ Psychol. 2011;84:327-46.

35. Berth $H$, Förster $P$, Brähler E. Unemployment, Job Insecurity and their Consequences for Health in a Sample of Young Adults. Gesundheitswesen. 2003;65:555-60.

36. Burgard SA, Brand JE, House JS. Perceived job insecurity and worker health in the United States. Soc Sci Med. 2009;69(5):777-85.

37. Mewes R, Rief W, Martin A, Glaesmer H, Brähler E. Job insecurity versus unemployment: unequal in socioeconomic status but comparable detrimental effects on mental health and health care utilization. Psychother Psychosom Med Psychol. 2013;63(3):138-44.

38. Zenger M, Hinz A, Petermann F, Brähler E, Stöbel-Richter Y. Health and Quality of Life within the Context of Unemployment and Job Worries. Psychother Psych Med. 2013;63:129-37.

39. Berth $H$, Förster $P$, Brähler E. Unemployment, job insecurity and lifesatisfaction: results of a study with young adults in the new German states. Soz Präventiv Med. 2005:50:1-9.

40. Amick BC, McDonough P, Chang H, Rogers WH, Pieper CF, Duncan G. Relationship between all-cause mortality and cumulative working life course psychosocial and physical exposures in the United States labor market from 1968 to 1992. Psychosom Med. 2002;64(3):370-81.

41. Perlman F, Bobak M. Assessing the Contribution of Unstable Employment to Mortality in Posttransition Russia: Prospective IndividualLevel Analyses From the Russian Longitudinal Monitoring Survey. Am J Public Health. 2009;99(10):1818-25.

42. Taylor MF, Brice J, Buck N, Prentice-Lane E. British Household Panel Survey User Manual Volume A: Introduction, Technical Report and Appendices. Colchester: University of Essex; 2010.

43. D'Souza RM, Strazdins L, Lim LL, Broom DH, Rodgers B. Work and health in a contemporary society: demands, control, and insecurity. J Epidemiol Community Health. 2003;57(11):849-54.

44. Lazarus R, Folkman S. Stress, appraisal and coping. New York: Springer; 1984

45. McEwen BS. Allostasis and allostatic load: implications for neuropsychopharmacology. Neuropsychopharmacol. 2000;22(2):108-24.

46. László KD, Engström K, Hallqvist J, Ahlbom A, Janszky I. Job insecurity and prognosis after myocardial infarction: the SHEEP Study. Int J Cardiol. 2013;167(6):2824-30

\section{Submit your next manuscript to BioMed Central and take full advantage of:}

- Convenient online submission

- Thorough peer review

- No space constraints or color figure charges

- Immediate publication on acceptance

- Inclusion in PubMed, CAS, Scopus and Google Scholar

- Research which is freely available for redistribution 